\title{
Polymorphism of glutathione S-transferase in the population of Polish patients with carcinoma of the prostate
}

\author{
Joanna M. Drozdz-Afelt ${ }^{1}$ (D) Beata Koim-Puchowska ${ }^{1} \cdot$ Grzegorz Klosowski ${ }^{1} \cdot$ Piotr Kaminski $^{2}$
}

Received: 8 October 2019 / Accepted: 13 March 2020 / Published online: 24 March 2020

(C) The Author(s) 2020

\begin{abstract}
The aim of the study was frequency analysis of GSTM1, GSTT1, and GSTP1 polymorphisms of glutathione S-transferase in the group of patients with prostate cancer and in a control group of healthy individuals. Genomic DNA was isolated; molecular analysis of glutathione S-transferase $M 1$ and $T 2$ polymorphisms was performed using multiplex PCR and RFLP methods. The products of the PCR reaction were then visualized in agarose gel, and a statistical analysis of the results was performed. No statistically significant differences were found in the frequency of glutathione S-transferase polymorphisms between 66 patients with prostate cancer and the control group (64 healthy volunteers). The GSTM1 gene deletion was found in ca. $47 \%$ of patients with prostate cancer and in ca. 55\% of the controls. The GSTT1 deletion was found in approximately $17 \%$ of patients and $14 \%$ of the controls. The distribution of GSTP1 Ile/Ile, Ile/Val, and Val/Val polymorphisms was ca. 51.5\%, 39\%, and 9\% in the group of patients and $61 \%, 34 \%$, and $5 \%$ in the control group, respectively. The results indicate that there is no relationship between glutathione S-transferase polymorphisms and prostate cancer in the study group, which is a novelty when compared with the previous work on the role of these genetic variants in the etiology of cancer.
\end{abstract}

Keywords Glutathione S-transferase · Glutathione S-transferase M1 · Glutathione S-transferase P1-1 · Glutathione S-transferase T1 $\cdot$ Polymorphism $\cdot$ Prostate cancer

\section{Introduction}

Over the last three decades, the incidence of malignant tumors has increased dramatically. Oncologists cite data showing that the diagnosis of cancer has doubled in Polish patients. Cancers are also the second leading cause of death. They are characterized by increasing incidence rate, ca. $1.96 \%$ on an annual basis in men in Poland (Didkowska et al. 2009; Wojtys et al. 2013; Didkowska and Wojciechowska 2015; Osowiecka et al. 2019).

Responsible editor: Philippe Garrigues

Joanna M. Drozdz-Afelt jdrozdz@ukw.edu.pl

1 Department of Biotechnology, Kazimierz Wielki University, Księcia Józefa Poniatowskiego St.12, PL, 85-671 Bydgoszcz, Poland

2 Department of Ecology and Environmental Protection, Collegium Medicum in Bydgoszczy, Nicolaus Copernicus University in Torun, M. Curie Skłodowskiej St.9, PL, 85-094 Bydgoszcz, Poland
Prostate cancer is currently one of the most common cancers, and the mortality associated with it is one of the highest among men, second only to lung cancer. Until the 1980, the incidence rate was dramatically increasing. After the introduction of screening for prostate-specific antigen (PSA), the incidence rate of prostate cancer stopped rising, remaining at a stable level (Kral et al. 2011; Osowiecka et al. 2019).

Despite the progress in understanding the basis of the disease, which includes the discovery of the role of testosterone, ongoing research is aimed at determining both environmental and genetic factors that increase the susceptibility to this disease (Ricks-Santi et al. 2010; Osowiecka et al. 2019).

Prostate cancer is the second most common malignant tumor in men which is most commonly seen in older adults. Over $80 \%$ of prostate cancer cases are diagnosed in men aged 65 or older (Daniyal et al. 2014), and the risk of developing the disease increases after the age of 50 (Nurzyński 2011). Prostate cancer mortality is low (10\%), but it is believed that the disease often remains undetected. Because of its high prevalence, health consequences, and mortality, prostate cancer has become one of the major health problems of the modern world (Daniyal et al. 2014). 
Until now the etiology of the disease has not been clearly defined despite the recognition of well-established risk factors, such as age (the main risk factor), ethnic and geographical origin, and family history of prostate cancer (Sivonová et al. 2009; Daniyal et al. 2014; Mandair et al. 2014; Szot et al. 2014). It is believed that environmental factors are responsible for the development of prostate tumors, but an important role is also attributed to genetic factors (Kral et al. 2011).

Studies showed that a patient whose father or brother suffered from prostate cancer has a 2-fold increased risk of developing the disease compared with the general population (Sivonová et al. 2009). Men with one, two, or three firstdegree relatives diagnosed with prostate cancer have, respectively, two-fold, five-fold, and eleven-fold increased risk of developing the disease, compared with those who did not report any history of familial prostate cancer (ZeiglerJohnson et al. 2008). Scandinavian studies involving twins suggested that inheritance of predisposing genes is responsible for $42 \%$ of prostate cancer cases; the remaining part is dependent on environmental factors (Wang et al. 2018).

The etiology of prostate cancer includes factors that the man was exposed to at home or at work (Nurzyński 2011). Recent studies highlight the impact of factors such as smoking, excessive alcohol consumption, high-fat diet, sexual behavior, and exposure to UV radiation or to carcinogenic substances (Sivonová et al. 2009; Daniyal et al. 2014; Szot et al. 2014). Occupational exposures include contamination with substances of industrial origin but also with pesticides used in agriculture (Szot et al. 2014).

Recent work focuses on gene polymorphisms that may be responsible for the increased susceptibility to prostate cancer (Ricks-Santi et al. 2010; Mittal et al. 2011). A number of polymorphisms responsible for the increase in the incidence of prostate cancer have been identified, and selected mutations in the CHECK2, NBS1, and BRCA1 genes are analyzed as markers. In addition, new population-specific changes that may increase the risk of prostate cancer are being sought (Mittal et al. 2011; Giri and Beebe-Dimmer 2016; Pritchard et al. 2016; Wang et al. 2018).

Studies on the identification of genetic polymorphisms of glutathione S-transferase (GST), one of the major enzymes involved in the inactivation of carcinogens, are being vigorously pursued. Due to their wide substrate specificity, glutathione S-transferases are an interesting research topic. Currently, extensively studied are GST polymorphisms that cause reduction or loss of enzymatic activity, i.e., GSTM1, GSTT1, and GSTP1. Reports on relationships between these genetic variants and neoplastic changes suggest their involvement in the etiology of colon, breast, lung, and prostate cancer. Despite the ambiguous results, it is suggested that the changes in the human glutathione S-transferase gene may be linked to the incidence of various types of cancer (Lavender et al. 2009; Chatterjee and Gupta 2018).
Glutathione S-transferases belong to a multigenic family that is responsible for the production of enzymes of phase II of xenobiotic metabolism (Mo et al. 2009; Kwon et al. 2011; Giri and Beebe-Dimmer 2016). These proteins catalyze the coupling of glutathione with electrophilic components mediating the removal of endogenous and exogenous substances from the body, including carcinogens (Lavender et al. 2009).

For example, GST enzymes are involved in the inactivation of such carcinogens as polycyclic aromatic hydrocarbons (PAHs), which are components of cigarette smoke, grilled meats, and diesel exhaust. GSTs are also involved in the detoxification of reactive oxygen species and endogenous steroid hormone metabolites (Nock et al. 2009). Other GST functions include modulation of various enzymes, e.g., those important for DNA repair (Mo et al. 2009).

GST enzymes are encoded by at least 8 distinct loci, each containing one or more homodimeric or heterodimeric isoforms. GSTT1, GSTM1, and GSTP1 belong to the beststudied loci (Mo et al. 2009). GSTT1 and GSTM1 are deletion variants resulting in the loss of enzymatic activity. GSTP1 is a polymorphism causing substitution inside the active site of the enzyme that leads to changes in conjugation activity and substrate-specific thermostability (Lavender et al. 2009; Benabdelkrim et al. 2018).

GST enzymes are primarily involved in the metabolism of xenobiotics including various potential carcinogens. Therefore, it is believed that they play a role in protecting the organism from toxic and carcinogenic components that get into the body in the form of contaminants, drugs, or food additives. It is suggested that people with loss-of-function genes or genes for altered enzymatic activity may have limited capacity to efficiently eliminate carcinogens, which may lead to their accumulation and consequently to an increased risk of mutations (Kwon et al. 2011; Benabdelkrim et al. 2018).

GSTM1 gene encodes a glutathione S-transferase that belongs to the mu class. The function of this enzyme is the detoxification of electrophilic substances such as drugs, various types of carcinogens (benzopyrene - a component of cigarette smoke), or products of oxidative stress. This is done by coupling with glutathione, in phase II of metabolism of xenobiotics (http://www.ncbi.nlm.nih.gov/gene/2944, Kwon et al. 2011; Weich et al. 2017).

It has been shown that the inheritance of the GSTMI deletion, i.e., the homozygous GSTM1 null genotype, leads to inactivity of this form of the enzyme. It is believed that the null genotype has a reduced ability to detoxify some carcinogens and therefore may be associated with an increased risk of solid tumors (Sivonová et al. 2009; Kwon et al. 2011; Weich et al. 2017).

According to Mo and co-workers 2009, the frequency of this polymorphism in Caucasians ranges from 13.1 to $54.5 \%$. Slovak researchers reported that the frequency of GSTM1 polymorphism among white Europeans ranges from 47 to 58\% (Sivonová et al. 2009). 
The GSTT1-theta 1 gene located on chromosome 22 (locus $22 \mathrm{q} 11.23$ ) is also a member of the superfamily of genes encoding proteins that catalyze the coupling of reduced glutathione with various hydrophobic and electrophilic compounds. This gene is probably involved in carcinogenesis processes. The function of GSTT1 is the detoxification of smaller, reactive hydrocarbons, e.g., ethylene oxide (http://www.ncbi. nlm.nih.gov/gene/2952, Kwon et al. 2011).

The GSTT1 null genotype leads to the lack of enzymatic activity of the protein, as in the case of the GSTM1 null polymorphism. Due to the reduced detoxification capacity of ethylene oxide metabolites, this variant can provide information on exposure to environmental or nutritional factors that can damage genetic material (Safarinejad et al. 2011; Kwon et al. 2011).

GSTT1 deletion is associated with an increased risk of developing ovarian, bladder, or lung cancer. The frequency of homozygous deletion of this gene was estimated at 11.1$28.6 \%$ in Caucasians (Mo et al. 2009), while the Slovak study reports 13-25\% in white Europeans (Sivonová et al. 2009).

GSTP1 is one of the major enzymes involved in the inactivation of carcinogenic substances found in cigarettes and cigarette smoke. Substances neutralized by GSTP1 include epoxide benzo-(alpha)-pyrene diol or acrolein, a compound that is a frequent environmental pollutant and exhibits a high reactivity with the cells (Harries et al. 1997; Safarinejad et al. 2011). It was also found that the gene coding for glutathione S-transferase is inactivated by hypermethylation at the early stages of prostate carcinogenesis and that its expression is also disturbed in samples of other cancers, which may suggest its role in the etiology of neoplastic diseases (Harries et al. 1997).

The best studied polymorphism GSTP1 Ile105Val, resulting from substitution of 105 Ile codon for Val codon, most probably leads to changes in the substrate-specific thermostability and affects the conjugation activity. When compared with the GSTP1 Ile/Ile variant, the GSTP1 Val/Val variant was associated with reduced detoxification of epoxy diols of certain polycyclic aromatic hydrocarbons (Buchard et al. 2007; Lavender et al. 2009; Shin et al. 2016).

According to meta-analysis of Mo et al. (2009), the frequency of this polymorphism, located at 11q13, for the Vall Val homozygous variant is about $9-12.6 \%$ in Caucasians. Sironova and co-workers 2009 cited the data on the frequency of heterozygotes Ile/ $\mathrm{Val}$ and homozygotes $\mathrm{Val} / \mathrm{Val}$ in the population of white Europeans, which was between 38 and $45.7 \%$ and between 7 and 13\%, respectively (http://www.ncbi.nlm. nih.gov/gene/2950).

The aim of this study was to analyze the frequency of polymorphic glutathione S-transferase (GSTM1, GSTT1, GSTP1) in patients with prostate cancer compared with the control group of healthy men from Poland. The polymorphisms listed above are an interesting research topic in the context of cancer. Prostate cancer is a multifactorial disease caused by genetic and environmental factors. Identification of carcinogens and genes responsible for prostate cancer susceptibility is an interesting topic for further studies aimed at a better understanding of the etiology of the disease.

\section{Materials and methods}

In the study, we used blood samples collected from 66 patients of the Oncology and Brachytherapy Department of the Oncology Center in Bydgoszcz with diagnosed prostate cancer and from 64 healthy volunteers recruited at the outpatient clinic (SP ZOZ) in Mogilno and the Department of Prevention and Health Promotion of the Oncology Center in Bydgoszcz.

Men with a recent blood transfusion were excluded from both the cancer group and the control. The control group consisted of men over 50 years old, so that the age of the sick and the controls was similar. Men were qualified to the control group based on surveys. First of all, their health was taken into account. In particular, the candidates had to meet the following requirements:

1. No diagnosed cancer history

2. No major surgical procedures

3. The results of PSA tests in the reference range (up to $4 \mathrm{ng}^{*} \mathrm{ml}^{-1}$ ) and normal prostate on digital rectal examination

The work was approved by Ethical Committee of Collegium Medicum in Bydgoszcz (KB 65/2012; consent dated February 28, 2012, and the relevant annexes).

The material for analysis was blood collected from the ulnar vein. For blood collection, we used 2-ml hematology tubes containing $\mathrm{K}_{3}$ EDTA.

In order to obtain separated serum, blood samples were centrifuged $\left(2000 \times g\right.$, for $15 \mathrm{~min}$, at $\left.4{ }^{\circ} \mathrm{C}\right)$, and the material needed for analysis was transferred to Eppendorf tubes. All tubes with test material were stored at $-80{ }^{\circ} \mathrm{C}$ until the planned analyzes were performed. DNA isolation from the blood was carried out using Master Pure ${ }^{\mathrm{TM}}$ DNA Purification Kit for Blood (Epicenter Biotechnologies, USA).

\section{GSTM1 and GSTT1 polymorphism analysis using multiplex PCR}

The material isolated from blood was amplified using the multiplex PCR method according to Gara et al. (2010). This method provides information on both deletions (GSTM1 and GSTT1) in one reaction.

The reaction solution contained $50 \mathrm{ng}$ DNA, $1 \mu \mathrm{l} 200 \mathrm{nmol}$ starters, $4 \mu \mathrm{l} 25 \mathrm{mM} \mathrm{MgCl} 2,5 \mu$ l reaction buffer $(10 \times), 1 \mu \mathrm{l}$ $10 \mathrm{mM}$ dNTPs, and $2 \mathrm{U}$ Taq polymerase. The volume of the solution was adjusted with water to $50 \mu$ l.

Three pairs of starters were used: GSTM1- sense G1 (GAACTCCCTGAAAA GCTAAAGC) 
GSTM1 - anti G2 (GTTGGGCTCAAATATACGGTGG) GSTT1 - sense T1 (TTCCTTACTGGTCCTCACAT CTC)

GSTT1 - anti T2 (TCACCGGATCATGGCCAGCA)

Albumin- sense A1 (GCCCTCTGCTAACAAGTCCT $\mathrm{AC})$

Albumin- anti A2 (GCCCTAAAAAGAAAATCGCC AATC)

Multiplex PCR proceeded according to the following protocol: DNA initial denaturation at $94{ }^{\circ} \mathrm{C}$ for $5 \mathrm{~min}$, initial hybridization at $64{ }^{\circ} \mathrm{C}$ for $2 \mathrm{~min}, 30$ cycles of elongation for $30 \mathrm{~s}$ at $72{ }^{\circ} \mathrm{C}$, denaturation for $20 \mathrm{~s}$ at $94{ }^{\circ} \mathrm{C}$, hybridization for $20 \mathrm{~s}$ at $64^{\circ} \mathrm{C}$, and then final extension for $7 \mathrm{~min}$ at $72^{\circ} \mathrm{C}$.

The resulting DNA fragments were then separated in a $1.5 \%$ agarose gel. The gels were stained with Midori Green reagent (a noncarcinogenic alternative to ethidium bromide) and run at $100 \mathrm{~V}$ for about $50 \mathrm{~min}$. The results were then visualized in a chamber equipped with a camera and UV lamp. pBR322 DNA/Alu I was run on the gel as a size marker.

The lack of amplification of $215 \mathrm{bp}$ and $480 \mathrm{bp}$ fragments indicated the presence of deletions in the GSTM1 and GSTT1 fragments, respectively. A fragment of albumin gene (380 bp) was used as a positive reaction control.

\section{GSTP1 polymorphism analysis using PCR-RFLP}

Genetic material isolated from blood was subjected to PCRRFLP, which allows to detect a given change in DNA by using an appropriate restriction enzyme. PCR and digestions were carried out according to the method developed by Harries et al. (1997).

The reaction solution contained $50 \mathrm{ng}$ DNA, $1 \mu 1200 \mathrm{nmol}$ starters, $2.4 \mu \mathrm{l} 25 \mathrm{mM} \mathrm{MgCl}_{2}, 4 \mu \mathrm{l}$ reaction buffer (10×), $1 \mu \mathrm{l}$ $10 \mathrm{mM}$ dNTPs, and $2 \mathrm{U}$ Taq polymerase. The volume of the solution was adjusted with water to $40 \mu \mathrm{l}$.

The following pair of starters was applied:

P105F (ACC CCA GGG CTC TAT GGG AA)

P105R (TGA GGG CAC AAG AAG CCC CT)

The obtained fragments were then digested with the restriction enzyme Alw26I using $20 \mu \mathrm{l}$ of PCR product, $4 \mathrm{U}$ of ALw26I, $2.5 \mu \mathrm{l}$ of Tango buffer (10×), and $2 \mu \mathrm{l}$ of $\mathrm{H}_{2} \mathrm{O}$. The reaction was carried out for $2 \mathrm{~h}$ at $37^{\circ} \mathrm{C}$. The resulting DNA fragments were then separated in a $4 \%$ agarose gel at $110 \mathrm{~V}$ for ca. $30 \mathrm{~min}$. The gels were stained with Midori Green reagent. The results were visualized in a chamber equipped with a camera and UV lamp. pUC/Msp I was run on the gel as a size marker. A 176-bp band on the agarose gel indicated the presence of the Ile/Ile polymorphism, two bands of $91 \mathrm{bp}$ and $85 \mathrm{bp}$ corresponded to the $\mathrm{Val} / \mathrm{Val}$ polymorphism, while the presence of all three bands in the gel path $(176 \mathrm{bp}, 91 \mathrm{bp}$, and
$85 \mathrm{bp}$ ) indicated the presence of a heterozygous variant of the GSTP1 Ile/ Val gene.

Statistical analysis was performed with STATISTICA 10 software for Windows 10 using descriptive statistics and statistical significance tests. In the first step, Shapiro-Wilk normality test was used to determine if the analyzed data were normally distributed. As the null hypothesis about the normality of the distribution was rejected for variables used in this work, between-group differences were analyzed using the Mann-Whitney U test. For all analyzes a significance level of $5 \%(p<0.05)$ was adopted.

\section{Results}

The results of molecular analysis of glutathione S-transferase polymorphisms were obtained in the form of digital images of electrophoretic gels for polymorphisms GSTM1 and GSTT1 (Fig. 1) and separately for the GSTP1 polymorphism (Fig. 2).

The results obtained by electrophoresis corresponded to a genotype present in the cancer group and in the control. There were no statistically significant differences between the groups for any of the three genotypes tested (Table 1; Fig. 3).

\section{Discussion}

Prostate cancer is currently one of the most commonly diagnosed cancers in men from developed countries. It is likely that its incidence will increase with increasing age of the population. Mechanisms of prostate carcinogenesis, involving both genetic and environmental factors, remain unclear. Changes in genes of DNA repair pathways that play a critical role in the prevention of carcinogenesis may lead to a higher susceptibility to cancer, including prostate cancer (Gong et al. 2012; Cai et al. 2014; Shin et al. 2016).

Glutathione S-transferases are superfamily of enzymes of the second phase of xenobiotic metabolism that play an important role in the genetics of prostate cancer. These enzymes catalyze the conjugation of chemically reactive compounds with reduced glutathione. They also protect DNA and other macromolecules from damage caused by oxidative stress. It is believed that the GSTM1 enzyme is involved in the metabolism of styrene oxide, the GSTT1 enzyme plays a role in the detoxification of dichloromethane and ethylene oxide, while the GSTP1 enzyme is responsible for the detoxification of carcinogenic heterocyclic amines. All these substances are probable carcinogens; therefore, the impaired function of the above-mentioned enzymes does not allow the efficient removal of toxic compounds, which indirectly may increase the susceptibility to various cancers, including prostate cancer. However, the mechanisms by which polymorphisms of the glutathione S-transferase can increase the risk of prostate 
Fig. 1 Electrophoretic separation of DNA fragments obtained by multiplex PCR, showing GSTM1 and GSTT1 deletion in the studied samples (lanes 1, 4, 6, and 9, patients with GSTM1+/GSTT1+ variant; lanes 2 and 7 , patients with GSTT1 deletion; lanes 3, 5, 8, and 10, patients with GSTM1 deletion), pBR322 DNA/Alu IDNA size marker

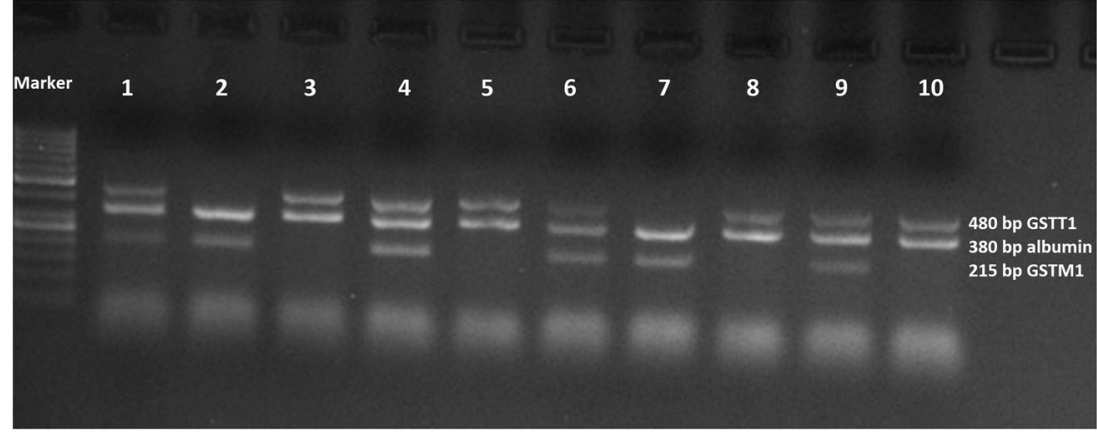

cancer are still unknown (Ntais et al. 2005; Cai et al. 2014; Chirilă et al. 2015; Qadri et al. 2011; Saheb et al. 2016).

The goal of this study was to determine whether the GSTM1, GSTT1, and GSTP1 polymorphisms can modify the risk of developing prostate cancer. We presented the results of the first-ever analysis of the frequency of glutathione Stransferase polymorphism in the group of Polish patients with prostate cancer and in a properly selected control group.

Statistical analysis of the results did not show statistically significant differences in the frequency of the polymorphisms between the analyzed groups. The deletion of GSTM1 was found in ca. $47 \%$ of patients with prostate cancer and in ca. $55 \%$ of controls. The GSTT1 deletion was found in ca. $17 \%$ of patients and ca. $14 \%$ of controls. In turn, the distribution of GSTP1 Ile/Ile, Ile/Val, and Val/Val polymorphisms was ca. $51.5 \%, 39 \%$, and $9 \%$ in the study group and $61 \%, 34 \%$, and $5 \%$ in the control, respectively.

Mo et al. (2009) in their meta-analysis reported the frequency of GSTM1 deletions in the range from 13.1 to $54.5 \%$ and the GSTT1 null polymorphism from 11.1 to $28.6 \%$. These authors provided previously published data on the frequency of the $\mathrm{Val} / \mathrm{Val}$ allele, from 9 to $12.6 \%$ in Caucasians, and also reported a higher percentage (38.9-62.1\%) obtained in their own study; the latter results may be distorted by including studies on combined variations Ile/Val and $\mathrm{Val} / \mathrm{Val}$. According to these data, the frequency of the GSTM1 and GSTT1 polymorphisms reported in our study for both the study group and the control are within the range found in the general population. It is interesting that a higher percentage of
GSTM1 deletions was observed in the control group (55\%), while in the study group, it was slightly lower (47\%). However, the difference was not statistically significant and might be due to the small number of people participating in the study, because each group contained less than 70 patients. In addition, no data on the frequency of GSTM1 deletion in the Polish population was available until now, which made it impossible to compare our results with the corresponding general population. The GSTP1 Val/Val frequency in the study group falls within the range previously observed in Caucasians, while in the control, the percentage is lower than expected, which was caused by a lower number of participants than in other studies. It should also be noted that similar low frequencies of the GSTP1 Val/Val allele in Caucasians were reported by other authors, e.g., Mittal and co-workers 2006, 4.8\%; or Srivastava and co-workers 2005, 3.5\%.

In their meta-analysis, Mo and co-workers 2009 found that the GSTM1 deletion increased the risk of prostate cancer in the general population, including Asians, Afro-Americans, and populations of African and Caucasian descent. In the case of the GSTT1 and GSTP1 polymorphisms, there were no statistically significant relationships with the disease (Mo et al. 2009); it was established that the polymorphisms are not related to the risk of prostate cancer.

Another meta-analysis by Gong and co-workers 2012 showed a significant association of GSTM1 polymorphism with the risk of prostate cancer; however, it did not find such correlations for the GSTT1 and GSTP1 deletions, thus confirming the results of Mo and co-workers 2009.
Fig. 2 Electrophoretic separation of DNA fragments obtained by PCR-RFLP, showing the presence of polymorphism Ile/Ile, Ile/Val, and $\mathrm{Val} / \mathrm{Val}$ GSTP1 in the studied samples (lanes 15, 16, 17, 22, 23, and 29, patients with the GSTP1 Ile/Ile genotype; lanes 19 and 21, patients with the Ile/Val GSTPI genotype; lane 24, a patient with the genotype GSTP1 $\mathrm{Val} / \mathrm{Val}$ ), pUC/MspI—DNA size marker

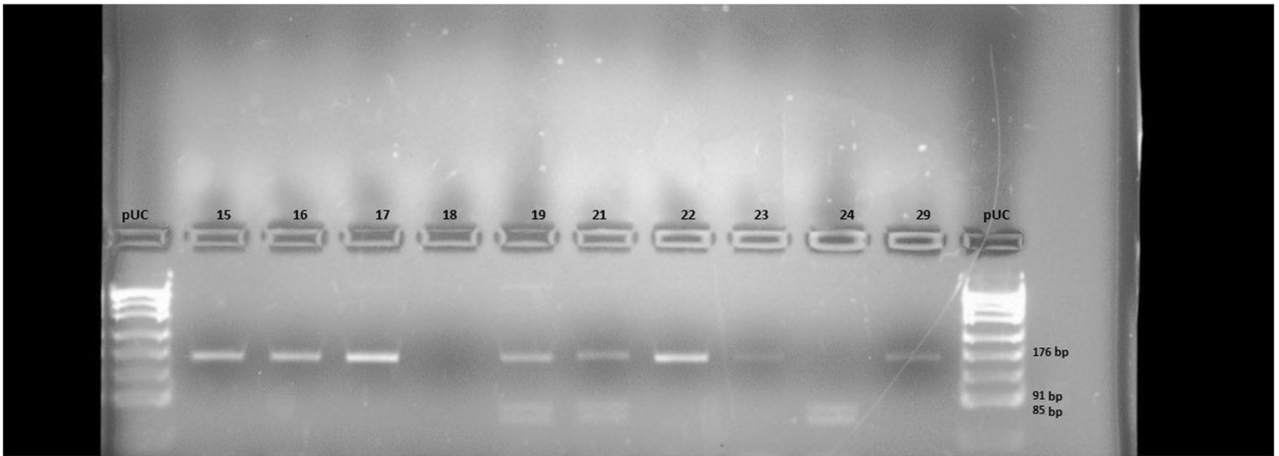


Table 1 Frequency of GSTM1, GSTT1, and GSTP1 polymorphisms in the cancer group $(n=66)$ and in the control $(n=64)$

\begin{tabular}{|c|c|c|c|c|c|c|}
\hline \multirow[t]{2}{*}{ Genotype } & & \multicolumn{2}{|c|}{ Cancer group } & \multicolumn{2}{|c|}{ Control group } & \multirow[t]{2}{*}{$p$} \\
\hline & & $N$ & $\%$ & $N$ & $\%$ & \\
\hline \multirow[t]{2}{*}{ GSTM1 genotype } & - & 31 & $46.97 \%$ & 35 & $54.69 \%$ & \multirow[t]{2}{*}{0.378} \\
\hline & + & 35 & $53.03 \%$ & 29 & $45.31 \%$ & \\
\hline \multirow[t]{2}{*}{ GSTT1 genotype } & - & 11 & $16.67 \%$ & 9 & $14.06 \%$ & \multirow[t]{2}{*}{0.68} \\
\hline & + & 55 & $83.33 \%$ & 55 & $85.94 \%$ & \\
\hline \multirow[t]{3}{*}{ GSTP1 genotype } & Ile/Ile & 34 & $51.52 \%$ & 39 & $60.94 \%$ & \multirow[t]{3}{*}{0.439} \\
\hline & $\mathrm{Val} / \mathrm{Val}$ & 6 & $9.09 \%$ & 3 & $4.69 \%$ & \\
\hline & Ile/Val & 26 & $39.39 \%$ & 22 & $34.38 \%$ & \\
\hline
\end{tabular}

Additionally, Gong and co-workers 2012 examined the combination of both genotypes and showed a significant increase in the risk of disease in men with double-null genotype GSTM1-/GSTT1- and those with GSTT1-/GSTP1 Ile/ Val. In this study, no comparison of combined phenotypes (GSTM1/T1/P1) was made due to the low number of men in the resulting subgroups making it impossible to obtain statistically significant results.

The latest meta-analysis by Cai and co-workers 2014 also showed significant relationships between prostate cancer and GSTM1 polymorphism in Caucasians and the lack of such correlations for GSTT1 allele. This meta-analysis did not include the study of genetic variants of glutathione S-transferase GSTP1. The latest reports on this polymorphism, cited in the meta-analysis of Wei and co-workers 2013, indicate a lack of dependence between GSTP1 Ile/Ile, Ile/Val, and Val/Val variants and an increased risk of prostate cancer. In general, these studies show the same results, but they also mention numerous limitations, such as the size of the study groups, their heterogeneity, or the lack of analysis for some populations. For example, to our knowledge, no studies have been conducted so far in Polish population on general frequency of

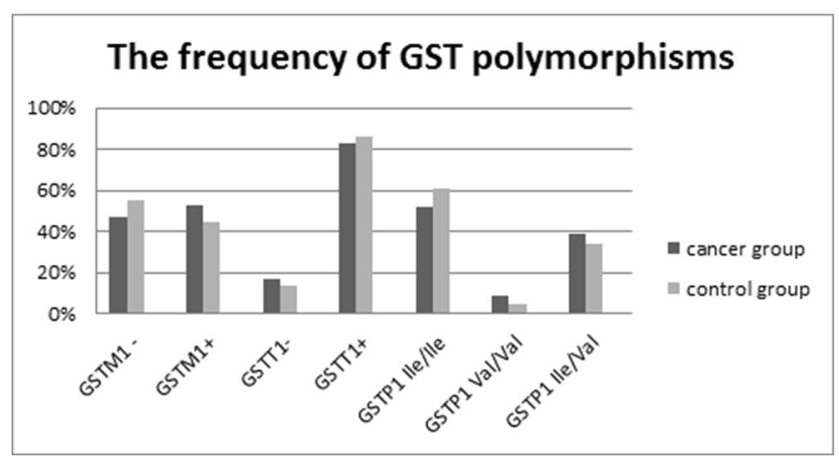

Fig. 3 Frequency of GSTM1, GSTT1, and GSTP1 polymorphisms in the cancer group ( $n=66)$ and in the control $(n=64)$ "GSTM1+," no deletion in the gene; "GSTM1-, " deletion of GSTM1; "GSTT1+," no deletion in the gene; "GSTT1-," deletion of GSTT1 polymorphisms of glutathione S-transferase and the relationships of these genetic changes with prostate cancer (cf. Mo et al. 2009; Gong et al. 2012; Cai et al. 2014).

The results presented in this paper, showing the frequency of genetic variants GSTM1, GSTT1, and GSTP1 confirm the lack of connection of glutathione S-transferase $T 1$ and $P 1$ polymorphisms with the risk of prostate cancer; however, they do not support claims that GSTM1 genetic variants may play a role in increasing the risk of this cancer. It should be noted that these are the first studies of this type, including Polish patients with prostate cancer, comparing the results with a properly selected control group.

This study showed that there was no relationship between glutathione S-transferase polymorphisms and prostate cancer in the analyzed group of patients, which makes our results different from those obtained in previous studies on the role of these genetic variants in cancer etiology.

Acknowledgments We thank Karolina Bombolewska for useful discussions and assistance in working at laboratory of genetic. We thank Ireneusz R. Moraczewski for his language assistance.

Author contributions All authors contributed to the study conception and design. Material preparation, data collection, and analysis were performed by Drozdz-Afelt Joanna and Koim-Puchowska Beata. The first draft of the manuscript was written by Drozdz-Afelt Joanna, and all authors commented on previous versions of the manuscript. All authors read and approved the final manuscript.

\section{Compliance with ethical standards}

Conflict of interest The authors declare that they have no conflict of interest.

Ethical approval All procedures performed in studies involving human participants were in accordance with the ethical standards of the institutional and/or national research committee and with the 1964 Helsinki declaration and its later amendments or comparable ethical standards.

The work was approved by Ethical Committee of Collegium Medicum in Bydgoszcz (KB 65/2012; consent dated February 28, 2012, and the relevant annexes).

Statement of informed consent Informed consent was obtained from all individual participants included in the study.

Open Access This article is licensed under a Creative Commons Attribution 4.0 International License, which permits use, sharing, adaptation, distribution and reproduction in any medium or format, as long as you give appropriate credit to the original author(s) and the source, provide a link to the Creative Commons licence, and indicate if changes were made. The images or other third party material in this article are included in the article's Creative Commons licence, unless indicated otherwise in a credit line to the material. If material is not included in the article's Creative Commons licence and your intended use is not permitted by statutory regulation or exceeds the permitted use, you will need to obtain permission directly from the copyright holder. To view a copy of this licence, visit http://creativecommons.org/licenses/by/4.0/. 


\section{References}

Benabdelkrim M, Djeffal O, Berredjem H (2018) GSTM1 and GSTT1 polymorphisms and susceptibility to prostate cancer: a case-control study of the Algerian population. Asian Pac J Cancer Prev 19:28532858

Buchard A, Sanchez JJ, Dalhoff K, Morling N (2007) Multiplex PCR detection of GSTM1, GSTT1, and GSTP1 gene variants: simultaneously detecting GSTM1 and GSTT1 gene copy number and the allelic status of the GSTP1 Ile105Val genetic variant. J Mol Diagn 9: 612-617

Cai Q, Wang Z, Zhang W, Guo X, Shang Z, Jiang N, Tian J, Niu Y (2014) Association between glutathione S-transferases M1 and T1 gene polymorphisms and prostate cancer risk: a systematic review and meta-analysis. Tumour Biol 35:247-256

Chatterjee A, Gupta S (2018) The multifaceted role of glutathione Stransferases in cancer. Cancer Lett 433:33-42

Chirilă DN, Popp R, Vesa S,, Bălăcescu O, Coman I, Constantea NA, Ciuce C (2015) GSTM1, GSTT1 and GSTP1 genetic variants in multiple urologic cancers. Chirurgia (Bucur) 110:54-61

Daniyal M, Siddiqui ZA, Akram M, Asif HM, Sultana S, Khan A (2014) Epidemiology, etiology, diagnosis and treatment of prostate cancer. Asian Pac J Cancer Prev 15:9575-9578

Didkowska J, Wojciechowska U, Zatoński W (2009) Prediction of cancer incidence and mortality in Poland up to the year 2025. Centrum Onkologii Instytut M. Sklodowskiej-Curie, Krajowy Rejestr Nowotworów (in Polish)

Gara S, Abessi M, Bendjemena K, Abdennebi M, Guemira F (2010) Deletion polymorphism of glutathione S-transferases M1 and T1 in the Tunisian population. Tunis Med 88:700-702

Giri VN, Beebe-Dimmer JL (2016) Familial prostate cancer. Semin Oncol 43:560-565

Gong M, Dong W, Shi Z, Xu Y, Ni W, An R (2012) Genetic polymorphisms of GSTM1, GSTT1, and GSTP1 with prostate cancer risk: a meta-analysis of 57 studies. PLoS One 7:e50587

Harries LW, Stubbins MJ, Forman D, Howard GC, Wolf CR (1997) Identification of genetic polymorphisms at the glutathione Stransferase pi locus and association with susceptibility to bladder, testicular and prostate cancer. Carcinogenesis 18:641-644

Kral M, Rosinska V, Student V, Grepl M, Hrabec M, Bouchal J (2011) Genetic determinants of prostate Cancer: a Reviev. Biomed Pap Med Fac Univ Palacky Olomouc Czech Repub 155(1):3-10

Kwon DD, Lee JW, Han DY, Seo IY, Park SC, Jeong HJ, Yang YS, Chae SC, Na KS, Mo KJ, Kim JJ, Rim JS (2011) Relationship between the glutathione-S-Transferase P1, M1, and T1 genotypes and prostate cancer risk in Korean subjects. Korean J Urol 52:247-252

Lavender NA, Benford ML, VanCleave TT, Brock GN, Kittles RA, Moore JH, Hein DW, Kidd LC (2009) Examination of polymorphic glutathione S-transferase (GST) genes, tobacco smoking and prostate cancer risk among men of African descent: a case-control study. BMC Cancer 9:397

Mandair D, Rossi RE, Pericleous M, Whyand T, Caplin ME (2014) Prostate cancer and the influence of dietary factors and supplements: a systematic review. Nutr Metab (Lond) 11:30

Mittal RD, Mishra DK, Mandhani A (2006) Evaluating polymorphic status of glutathione-S-transferase genes in blood and tissue samples of prostate cancer patients. Asian Pac J Cancer Prev 7:444-446

Mittal RD, George GP, Mishra J, Mittal T, Kapoor R (2011) Role of functional polymorphisms of P53 and P73 genes with the risk of prostate cancer in a case-control study from northern India. Arch Med Res 42:122-127
Mo Z, Gao Y, Cao Y, Gao F, Jian L (2009) An updating meta-analysis of the GSTM1, GSTT1, and GSTP1 polymorphisms and prostate cancer: a HuGE review. Prostate 69:662-688

Nock NL, Bock C, Neslund-Dudas C, Beebe-Dimmer J, Rundle A, Tang D, Jankowski M, Rybicki BA (2009) Polymorphisms in glutathione S-transferase genes increase risk of prostate cancer biochemical recurrence differentially by ethnicity and disease severity. Cancer Causes Control 20:1915-1926

Ntais C, Polycarpou A, Ioannidis JP (2005) Association of GSTM1, GSTT1, and GSTP1 gene polymorphisms with the risk of prostate cancer: a meta-analysis. Cancer Epidemiol Biomark Prev 14:176181

Nurzyński P (2011) Prostata. Schorzenie, leczenie, profilaktyka. Grupa Wydawnicza Weltbild:7-8 (in Polish)

Osowiecka K, Nawrocki S, Kurowicki M, Rucinska M (2019) The waiting time of prostate Cancer patients in Poland. Int J Environ Res Public Health 16

Pritchard CC, Mateo J, Walsh MF, de Sarkar N, Abida W, Beltran $\mathrm{H}$, Garofalo A, Gulati R, Carreira S, Eeles R, Elemento O, Rubin MA, Robinson D, Lonigro R, Hussain M, Chinnaiyan A, Vinson J, Filipenko J, Garraway L, Taplin ME, AlDubayan S, Han GC, Beightol M, Morrissey C, Nghiem B, Cheng HH, Montgomery B, Walsh T, Casadei S, Berger M, Zhang L, Zehir A, Vijai J, Scher HI, Sawyers C, Schultz N, Kantoff PW, Solit D, Robson M, van Allen E, Offit K, de Bono J, Nelson PS (2016) Inherited DNA-repair gene mutations in men with metastatic prostate Cancer. N Engl J Med 375:443-453

Qadri Q, Sameer AS, Shah ZA, Hamid A, Alam S, Manzoor S, Siddiqi MA (2011) Genetic polymorphism of the glutathioneS-transferase P1 gene (GSTP1) and susceptibility to prostate cancer in the Kashmiri population. Genet Mol Res 10:30383045

Ricks-Santi L, Mason T, Apprey V, Ahaghotu C, McLauchlin A, Josey D, Bonney G, Dunston GM (2010) p53 Pro72Arg polymorphism and prostate cancer in men of African descent. Prostate 70:1739-1745

Safarinejad MR, Shafiei N, Safarinejad SH (2011) Glutathione Stransferase gene polymorphisms (GSTM1, GSTT1, GSTP1) and prostate cancer: a case-control study in Tehran, Iran. Prostate Cancer Prostatic Dis 14:105-113

Saheb YSA, AL-Rubai'e SH, Yaseen NY, Suleiman AA (2016) Association of human GSTM1 and GSTT1 genes polymorphisms with prostate tumors in population of the south provinces of Iraq. Int J Curr Microbiol App Sci 5(12):678-686

Shin YE, Hwang IW, Jin HJ (2016) Association between glutathione Stransferases M1, T1 and P1 gene polymorphisms and prostate cancer in Koreans. Genes Genom 38(2):235-241

Sivonová M, Waczulíková I, Dobrota D, Matáková T, Hatok J, Racay P, Kliment J (2009) Polymorphisms of glutathione-S-transferase M1, T1, P1 and the risk of prostate cancer: a case-control study. J Exp Clin Cancer Res 28:32

Srivastava DS, Mandhani A, Mittal B, Mittal RD (2005) Genetic polymorphism of glutathione S-transferase genes (GSTM1, GSTT1 and GSTP1) and susceptibility to prostate cancer in northern India. BJU Int 95:170-173

Szot W, Kostkiewicz M, Zając J, Owoc A, Bojar I (2014) Prostate cancer in patients from rural and suburban areas-PSA value, Gleason score and presence of metastases in bone scan. Ann Agric Environ Med 21:888-892

Wang G, Zhao D, Spring DJ, DePinho RA (2018) Genetics and biology of prostate cancer. Genes Dev 32:1105-1140

Wei B, Zhou Y, Xu Z, Ruan J, Cheng H, Zhu M, Hu Q, Jin K, Yan Z, Zhou D, Xuan F, Zhou H, Wang Z, Huang X, Wang Q (2013) GSTP1 Ile105Val polymorphism and prostate cancer risk: evidence from a meta-analysis. PLoS One 8:e71640 
Weich N, Roisman A, Cerliani B, Aráoz HV, Chertkoff L, Richard SM, Slavutsky I, Larripa IB, Fundia AF (2017) Gene polymorphism profiles of drug-metabolising enzymes GSTM1, GSTT1 and GSTP1 in an Argentinian population. Ann Hum Biol 44: 379-383

Wojtys P, Godlewski D, Antczak A (2013) Predictions of cancer incidence in Poland in 2019. Centr Eur J Med 8(2):185-191

Zeigler-Johnson CM, Spangler E, Jalloh M, Gueye SM, Rennert H, Rebbeck TR (2008) Genetic susceptibility to prostate cancer in men of African descent: implications for global disparities in incidence and outcomes. Can J Urol 15:3872-3882

\section{Online document}

Didkowska J, Wojciechowska U (2015) Zachorowania i zgony na nowotwory złośliwe w Polsce. Krajowy Rejestr Nowotworów, Centrum Onkologii - Instytut im. Marii Skłodowskiej - Curie. http://onkologia.org.pl/wp-content/uploads/Nowotwory_2015.pdf/. Accessed 26 Mar 2015 (in Polish)

Publisher's note Springer Nature remains neutral with regard to jurisdictional claims in published maps and institutional affiliations. 